\title{
Морфометричний аналіз особливостей ремоделювання структур клубової кишки при резекціях різних об’емів паренхіми печінки
}

\begin{abstract}
Мета роботи: за допомогою морфологічних методів вивчити особливості ремоделювання структур клубової кишки при резекції різних об’ємів паренхіми печінки.

Матеріали і методи. Комплексом морфологічних методів досліджено клубову кишку 45 статевозрілих білих щурів-самців, які були розділені на 3-ри групи. 1-ша група нараховувала 15 інтактних тварин, 2-га - 15 щурів, у яких було видалено 31,5 \% паренхіми печінки, 3-тя - 15 тварин після резекції 58,1 \% паренхіми печінки. Евтаназію щурів здійснювали кровопусканням в умовах тіопенталового наркозу через один місяць від початку експерименту. Із клубової кишки виготовляли гістологічні мікропрепарати. Вимірювали товщини слизової, м’язової, серозної оболонок, підслизового прошарку, довжину та ширину ворсинок, глибину, ширину крипт, висоту покривних епітеліоцитів, діаметр їх ядер, визначали ядерно-цитоплазматичні відношення в епітеліоцитах, відносний об'єм ушкоджених епітеліоцитів, підслизово-слизовий та підслизово-м’язовий індекси, стромально-міоцитарні відношення у м’язовій оболонці органа. Кількісні показники обробляли статистично.

Результати досліджень та їх обговорення. Встановлено, що при резекції 31,5 \% паренхіми печінки досліджувані морфометричні показники змінювалися незначно. Найбільш зміненими виявилися морфометричні параметри структур клубової кишки через місяць після резекції 58,1 \% паренхіми печінки. При цьому товщина слизової оболонки досліджуваного органа з високим ступенем достовірності (р < 0,001) зменшилася на 15,0 \%, м'язової - на 6,1 \%, а товщина підслизового прошарку зросла на 7,4 \%, серозної оболонки - на 6,6 \%. Підслизово-слизовий індекс збільшився на 27,2 \%, а підслизово-м'язовий - на 14,4 \%, порівняно з контрольними морфометричними показниками. Довжина ворсинок та глибина крипт клубової кишки, висота епітеліоцитів статистично достовірно (р<0,001) зменшилися, відповідно, на 15,7 \%, 15,4 \% та 14,7 \%, а ширина ворсинок і крипт збільшилися на 13,3 \% і 14,2 \%. Ядерно-цитоплазматичні відношення у епітеліоцитах слизової оболонки клубової кишки виявилися зміненими на 38,5 \%, що свідчило про виражене порушення структурного клітинного гомеостазу. Відносний об'єм ушкоджених епітеліоцитів зріс у 28 разів, а стромально-міоцитарні відношення у м'язовій оболонці збільшилися на 22,6 \%, вказуючи на виражене зростання строми у м’язовій оболонці органа. Результати проведеного дослідження стверджують, що видалення великих об’ємів паренхіми печінки призводять до вираженої морфологічної перебудови (ремоделювання) структур клубової кишки, що характеризується нерівномірними диспропорційними змінами просторових характеристик структур органа, порушенням відношень між ними, судинними розладами, набряком, дистрофічними, некробіотичними змінами епітеліоцитів, ендотеліоцитів, стромальних елементів, інфільтративними та склеротичними процесами.
\end{abstract}

Ключові слова: резекція печінки; клубова кишка; ремоделювання.

Постановка проблеми і аналіз останніх досліджень та публікацій. Резекцію печінки нерідко виконують сьогодні в сучасних хірургічних клініках. Вказану операцію здійснюють при доброякісних та злоякісних пухлинах, метастазах, травмах печінки, внутрішньопечінковому холангіолітіазі, альвеолярному ехінококозі, трансплантації печінки [2, 9, 11]. Резекція великих об'ємів печінки може призводити до різних пострезекційних ускладнень: кровотечі з варикозно розширених вен стравоходу, шлунка, прямої кишки; асциту; спленомегалії; вторинного гіперспленізму; паренхіматозної жовтяниці; портосистемної енцефалопатії; печінкової недостатності; портальної гіпертензії [2, 3, 11]. Пострезекційна портальна гіпертензія призводить до структурної перебудови органів басейну ворітної печінкової вени, а також ремоделювання їх структур. Клубова кишка належить до органів, венозний дренаж від яких здійснюється через ворітну печінкову вену, де гемодинамічні розлади ускладнюються різними морфологічними змінами в судинах та струк- турах вказаного органа. Варто зазначити, що особливості ремоделювання структур клубової кишці при пострезекційній портальній гіпертензії вивчені недостатньо [10].

Мета роботи: за допомогою морфологічних методів вивчити особливості ремоделювання структур клубової кишки при резекції різних об’ємів паренхіми печінки.

Матеріали і методи. Комплексом морфологічних методів досліджено клубову кишку 45 статевозрілих білих щурів-самців, які були розділені на 3-ри групи. 1-ша група (контрольна) нараховувала 15 інтактних тварин, 2-га - 15 щурів, у яких було видалено ліву бокову частку - 31,5 \% паренхіми печінки, 3-тя - 15 тварин після резекції лівої та правої бокових часток - 58,1 \% паренхіми печінки [3]. Щурі знаходилися в умовах віварію на звичайному раціоні. За тваринами проводили постійний нагляд. Їх регулярно зважували, спостерігали за активністю, апетитом, за шерстяним покривом. Хворих щурів для експеримен- 
тальних досліджень не використовували. Евтаназію дослідних тварин здійснювали кровопусканням в умовах тіопенталового наркозу через один місяць від початку експерименту. Усі маніпуляції та евтаназію щурів проводили 3 дотриманням основних принципів роботи з експериментальними тваринами відповідно до положення “Європейської конвенції про захист хребетних тварин, які використовуються для експериментальних та інших наукових цілей” (Страсбург, 1986 р.), “Загальних етичних принципів експериментів на тваринах”, ухвалених першим національним конгресом із біоетики (Київ, 2001 р.), а також Закону України „Про захист тварин від жорстокого поводження” (від 21.02.2006) [ 4 ].

Вирізані шматочки із клубової кишки фіксували в 10 \% нейтральному розчині формаліну і після відповідного проведення через етилові спирти зростаючої концентрації заливали у парафінові блоки за загальноприйнятою методикою. Гістологічні зрізи завтовшки 5-7 мкм після депарафінізації фарбували гематоксилін-еозином, за ванГізон, Маллорі, Вейгертом, толуїдиновим синім [8]. Морфометрично на мікропрепаратах вимірювали товщину слизової (ТСО), м’язової (ТМО), серозної (ТСерО) оболонок, підслизового прошарку (ТПП), довжину (ДВ), ширину (ШВ) ворсинок, глибину (ГК), ширину (ШК) крипт, висоту покривних епітеліоцитів (ВПЕ), діаметр їх ядер (ДЯЕ). Визначали також ядерно-цитоплазматичні відношення (ЯЦВ) у епітеліоцитах, відносний об’єм ушкоджених епітеліоцитів (ВОУЕ), підслизово-слизовий (ПСІ) та підслизово-м'язовий (ПМI) індекси, стромально-міоцитарні відно- шення у м’язовій оболонці органа [1]. Морфометрію вказаних структур проводили за допомогою світлового мікроскопа “Olimpus BX-2“ з цифровою відеокамерою та пакетом прикладних програм “Відео Тест 5,0” та ”Відео розмір 5,0”. Кількісні величини обробляли статистично. Обробку результатів виконано у відділі системних статистичних досліджень ДВНЗ “Тернопільський державний медичний університет імені I. Я. Горбачевського MO3 України” в програмному пакеті Statsoft STATISTIKA. Різницю між порівнювальними величинами визначали за критеріями Манна-Уітні та Стьюдента [5].

Результати досліджень та їх обговорення. Отримані морфометричні параметри структур клубової кишки дослідних тварин представлені в таблиці 1. Усестороннім аналізом наведених у вказаній таблиці даних встановлено, що через місяць після резекції 31,5 \% паренхіми печінки вони змінювалися незначно. У досліджуваних експериментальних умовах товщини слизової, м’язової, серозної оболонок виявилися зміненими відповідно на 2,6; 1,4 та 1,1 \%, а товщина підслизового прошарку - всього на 0,9%. Необхідно зазначити, що підслизово-слизовий та підслизово-м'язовий індекси через місяць після резекції 31,5 \% паренхіми печінки суттєво не змінювалися ( $>0,05)$, вказуючи на стабільність органного структурного гомеостазу [7].

Висота ворсинок клубової кишки в даних експериментальних умовах зменшилася на 3,5 \% $(\mathrm{p}<0,05)$ порівняно 3 аналогічними контрольними величинами, а їх ширина статистично досто-

Таблиця 1. Морфометрична характеристика структур клубової кишки дослідних тварин (M士m)

\begin{tabular}{||l|c|c|c||}
\hline \multirow{2}{*}{ Показник } & \multicolumn{3}{|c||}{ Група спостереження } \\
\cline { 2 - 4 } & 1 -ша & 2 -га & 3 -тя \\
\hline ТСО, мкм & $320,4 \pm 4,5$ & $312,10 \pm 4,14$ & $31,80 \pm 0,36^{* *}$ \\
\hline ТПП, мкм & $29,60 \pm 0,39$ & $29,80 \pm 0,42$ & $58,90 \pm 0,66^{*}$ \\
\hline ТМО, мкм & $62,70 \pm 0,84$ & $61,80 \pm 0,81$ & $5,65 \pm 0,06^{*}$ \\
\hline Т СерО, мкм & $5,30 \pm 0,06$ & $5,36 \pm 0,05$ & $0,117 \pm 0,002^{* * *}$ \\
\hline ПСІ & $0,092 \pm 0,001$ & $0,095 \pm 0,003$ & $0,540 \pm 0,007^{* * *}$ \\
\hline ПМІ & $0,472 \pm 0,006$ & $0,482 \pm 0,003$ & $122,70 \pm 1,41^{* * *}$ \\
\hline ДВ, мкм & $145,5 \pm 1,8$ & $140,4 \pm 1,5^{*}$ & $62,20 \pm 0,69 * * *$ \\
\hline ШВ, мкм & $54,90 \pm 0,72$ & $56,90 \pm 0,75^{*}$ & $77,30 \pm 0,93^{* * *}$ \\
\hline ГК, мкм & $91,35 \pm 1,20$ & $87,80 \pm 1,20 *$ & $32,90 \pm 0,42^{* * *}$ \\
\hline ШК, мкм & $28,80 \pm 0,36$ & $29,96 \pm 0,33^{*}$ & $9,30 \pm 0,12^{* * *}$ \\
\hline ВЕ, мкм & $10,90 \pm 0,15$ & $10,70 \pm 0,18$ & $3,31 \pm 0,03$ \\
\hline ДЯЕ, мкм & $3,30 \pm 0,03$ & $3,28 \pm 0,03$ & $0,126 \pm 0,003^{* * *}$ \\
\hline ЯЦВЕ & $0,091 \pm 0,002$ & $0,094 \pm 0,003$ & $64,50 \pm 0,72^{* * *}$ \\
\hline ВОУЕ, \% & $2,30 \pm 0,03$ & $6,20 \pm 0,06^{* * *}$ & \\
\hline \hline
\end{tabular}

Примітка. *-p<0,05; **-p<0,01; ***-p<0,001 порівняно з 1-ю групою спостережень. 
вірно (p<0,05) збільшилася на 3,6 \%. Виявлені зміни довжини та ширини ворсинок слизової оболонки клубової кишки через місяць після видалення 31,5 \% паренхіми печінки свідчили, що площа їх всмоктувальної поверхні не змінювалася. Глибина крипт при цьому зменшилася на 3,9 \%, а їх ширина зросла на 4,0 \%. Висота покривних епітеліоцитів слизової оболонки клубової кишки, діаметри їх ядер, ядерно-цитоплазматичні відношення в цих клітинах не змінювалися через місяць після резекції 31,5 \% паренхіми печінки. Постійність ядерно-цитоплазматичних відношень в епітеліоцитах при цьому вказували на стабільність клітинного структурного гомеостазу [7].

Відносний об'єм ушкоджених ендотеліоцитів при цьому статистично достовірно $(\mathrm{p}<0,001)$ зріс 3 $(2,60 \pm 0,03)$ до $(6,90 \pm 0,06) \%$, тобто в 3 рази. Серед ушкоджених епітеліоцитів спостерігалися переважно дистрофічно та апоптично змінені клітини.

Через місяць після резекції 58,1 \% паренхіми печінки світлооптично в мікропрепаратах клубової кишки спостерігалося розширення та повнокров'я переважно венозних судин. У венозній ланці мікрогемоциркуляторного русла спостерігали переповнені кров'ю мікросудини, стази, тромбози, діапедезні паравазальні крововиливи, набряк, плазморагія стінок судин та паравазальних тканин. Описне свідчило про наявність пострезекційної портальної гіпертензії.

Найбільш зміненими виявилися морфометричні параметри структур клубової кишки через місяць після резекції 58,1 \% паренхіми печінки. У досліджуваних експериментальних умовах товщина слизової оболонки досліджуваного органа з високим ступенем достовірності $(\mathrm{p}<0,001)$ зменшилася на 15,0 \%, м'язової - на 6,1%. Товщина підслизового прошарку при цьому зросла на 7,4 \%, а серозної оболонки - на 6,6 \%. Підслизово-слизовий індекс виявився збільшеним на $27,2 \%$, а підслизово-м'язовий - на 14,4 \%, порівняно з контрольними морфометричними показниками. Довжина ворсинок та глибина крипт клубової кишки статистично достовірно $(\mathrm{p}<0,001)$ зменшилися при цьому, відповідно, на 15,7 \% та $15,4 \%$, а ширина ворсинок і крипт збільшилися на $13,3 \%$ та $14,2 \%$. Виражено $(\mathrm{p}<0,001)$ у даних експериментальних умовах на 14,7 \% зменшилася висота покривних епітеліоцитів слизової оболонки клубової кишки. Зниження товщини слизової оболонки, висоти ворсинок та епітеліоцитів свідчили про атрофічні процеси у досліджуваному органі, зумовлені венозним повнокров'ям та гіпоксією. 3 високим ступенем статистичної достовірнос- ті $(\mathrm{p}<0,001)$ на 38,5 \% виявилися зміненими ядерно-цитоплазматичні відношення у епітеліоцитах слизової оболонки клубової кишки, що свідчило про виражене порушення структурного клітинного гомеостазу [8]. Відносний об'єм ушкоджених епітеліоцитів із вираженою статистично достовірною різницею $(\mathrm{p}<0,001)$ зріс у 28 разів порівняно 3 контрольним морфометричним параметром і дорівнював $(64,50 \pm 0,72) \%$. Стромально-міоцитарні відношення у м'язовій оболонці неушкодженої клубової кишки дорівнювали $(0,124 \pm 0,001)$, а через місяць після резекції 58,1 \% паренхіми печінки - $(0,152 \pm 0,003)$. Наведені морфометричні параметри між собою статистично достовірно $(\mathrm{p}<0,001)$ відрізнялися і останній кількісний морфологічний показник перевищував попередній на 22,6 \%, вказуючи на виражене збільшення строми у м'язовій оболонці органа. Виражене порушення органного, тканинного та клітинного структурних гомеостазів може призводити до дисфункції органа.

Гістологічно в оболонках стінки клубової кишки спостерігалися виражені судинні розлади, набряки строми, осередки дистрофічно, некробіотично, апоптично змінених епітеліоцитів, вогнищеві інфільтрати та розростання сполучної тканини. Спостерігали також набряк ендотеліоцитів, їх дистрофію, некробіоз, десквамацію та проліферацію. Останнє свідчило про наявність гіпоксії. Виражене пошкодження більшості ендотеліоцитів може призводити до ендотеліальної дисфункції та посилювати ушкодження клітин та тканин [6]. Варто також зазначити, що виявлені патогістологічні ушкодження стінки клубової кишки в умовах пострезекційної портальної гіпертензії корелювали з такими морфометричними параметрами, як підслизово-слизовий, підслизово-м'язовий індекси, ядерно-цитоплазматичні відношення у епітеліоцитах, стромально-міоцитарні відношення у м'язовій оболонці органа, відносний об'єм ушкоджених епітеліоцитів.

На основі отриманих результатів проведеного дослідження та даних літератури можна стверджувати, що видалення великих об'ємів паренхіми печінки призводить не тільки до портальної гіпертензії, але й вираженої структурної перебудови (ремоделювання) структур клубової кишки кишки, що характеризується нерівномірними диспропорційними змінами просторових характеристик структур органа, порушенням відношень між ними, судинними розладами, набряком, дистрофічними, некробіотичними змінами епітеліоцитів, ендотеліоцитів, стромальних елементів, інфільтративними та склеротичними процесами. 
Висновок. Видалення 58,1 \% паренхіми печінки призводить до вираженого ремоделювання клубової кишки, яке характеризується диспропорційними нерівномірними змінами морфометричних параметрів слизової, м'язової, серозної оболонок, підслизового прошарку, ворсинок, крипт, епітеліоцитів, порушенням відношень між просторовими характеристиками оболонок органа, ядром та цитоплазмою епітелоцитів, стромальними структурами та міоцитами у м'язовій обо-

\section{СПИСОК ЛІТЕРАТУРИ}

1. Автандилов Г. Г. Основы количественной патологической анатомии / Г. Г. Автандилов. - М. : Медицина, 2002. - 240 с.

2. Вишневський В. А. Сегментарне резекции, отдаленные результаты при злокачественных опухолях печени / В. А. Вишневский, М. Г. Ефанов, И. В. Казаков // Укр. журнал хірургіï. - 2012. - № 1 (16). - С. 5-15.

3. Гнатюк М. С. Морфометрична оцінка особливостей ремоделювання структур дванадцятипалої кишки при резекції різних об’ємів печінки / М. С. Гнатюк, Л. В. Татарчук, О. Б. Ясіновський // Науковий вісник Ужгородського університету. Серія “Медицина”. - 2016. - Вип. 1 (53). - С. 92-95.

4. Загальні етичні принципи експериментів на тваринах // Ендокринологія. - 2003. - Т. 8, № 1. - С. 142-145.

5. Лапач С. Н. Статистические методы в медико-биологических исследованиях Excell / C. Н. Лапач, А. В. Губенко, П. Н. Бабич. - К. : Морион, 2001. - 410 с.

6. Макаров М. А. Роль дисфункции эндотелия и регидности артерий в патогенезе хронической обструктивной болезни легких / М. А. Макаров, С. Н. Авдеев, А. Г. Чучалин // Тера-

\section{REFERENCES}

1. Avtadnilov, G.G. (2002). Osnovy kolichestvennoy patologicheskoy anatomii [Basis of quantitative pathological anatomy]. Moscow: Meditsina [in Russian].

2. Vishnevskiy, V.A., Yefanov, M.G., \& Kazakov, I.V. (2012). Segmentarnyye rezektsyi, otdalennyye rezultaty pri zlokachestvennykh opukholyakh pecheni [Segmentar resections, long-term results in malignant liver tumors]. Ukr. Zhurnal Khirurgii - Ukrainian Journal of Surgery, 1 (16), 5-15 [in Russian].

3. Hnatiuk, M.S., Tatarchuk, L.V., \& Yasinovskyi, O.B. (2016). Morfometrychna otsinka osoblyvostei remodeliuvania struktur dvanadtsiatypaloi kyshky pry resektsii riznykh obiemiv pechinky [Morphometric evaluation of the features of remodeling of duodenal structures during resection of different volumes of the liver]. Naukovyi visnyk Uzhhorodskoho universytetu. Seriia "Medytsyna" - Scientific Journal of Uzhhorod University. Series "Medicine", 1 (49), 3-5 [in Ukrainian].

4. (2003). Zahalni etychni pryntsypy eksperymentiv na tvarynakh [General ethical principles of experiments on animals]. Endokrynolohiia - Endocrinology, 8, 1, 142-145 [in Ukrainian]. 5. Lapach, S.N., Gubenko, A.V. Babich, P.N. (2001). Statistichieskiye metody vmediko-biologicheskikh issledovaniyakh Excell [Statistical methods in medicobiological investigations Excell]. Kyiv: Morion [in Ukrainian].

6. Makarov, M.A., Avdyeev, S.H., \& Chuchalin, A.G. (2012) Rol disfunktsyi endoteliya i regidnosti arteriy $\mathrm{v}$ patogeneze лонці, вираженим зростанням відносного об’єму ушкоджених епітеліоцитів, що може призводити до дисфункції ушкодженого органа.

Перспективи подальших досліджень. Всебічне адекватне вивчення закономірностей ремоделювання структур клубової кишки в умовах пострезекційної портальної гіпертензії дозволить суттєво розширити діагностику, корекцію та профілактику досліджуваної патології.

певтический архив. - 2012. - № 3. - С. 74-80.

7. Саркисов Д. С. Структурне основы адаптации и компенсации нарушенных функций / Д. С. Саркисов. - М. : Медицина, 1998. -230 с.

8. Сорочинников А. Г. Гистологическая и микроскопическая техника / А. Г. Сорочинников, А. Е. Доросевич. - М. : Медицина. - 2007. - 448 с.

9. Федоров В. Д. Основные осложнения обширных резекций печени и пути их предупреждения / В. Д. Федоров, В. А. Вишневский, Н. А. Назаренко [и др.] // Бюлл. сибирской медицины. - 2007. - № 4. - С. 16-24.

10. Шульгай А. Г. Особливості ремоделювання судин гемомікроциркуляторного русла клубової кишки при резекціях різних об’ємів печінки / А. Г. Шульгай, Л. В. Татарчук, М. С. Гнатюк // Вісник наукових досліджень. - 2017. - № 4. С. 148-149. 11. 11. Nanashima A. A modified grading system for posthepatectomy metastatic liver

12. cancer originating form colorectal carcinoma / A. Nanashima, Y. Sumida, T. Abo // J. Surg. Oncol. - 2008. - No. 98. - P. 363-370.

khronicheskoy obstruktivnoy bolezni legkikh [Role of disfunction of endothelial cell in medical and biological investigation]. Terapevticheskiy arkhiv - Theraputical archive, 3,74-80.

7. Sarkisov, D.S. (1998). Strukturnye osnovy adaptatsyi $i$ kompensatsyi narushennykh funktsyy [Structural basis adaptation and compensation damage function]. Moscow: Meditsina [in Russian].

8. Sorochinnikov, A.G., \& Dorosyevich, A.Ye. (2007). Gistologichieskaya i mikroskopicheskaya tekhnika [Histological and microscopic equipments]. Moscow: Meditsyna [in Russian]. 9. Fiodorov, V.D., Vishnevskiy, V.A., \& Nazarenko, N.A. (2007). Osnovnye oslozhneniya obshyrnykh rezektsyy pecheni i puti ikh preduprezhdeniya [The main complications of extensive liver resections and ways to prevent them]. Byull. Sibirskoy meditsyny - Bulletin of Siberian Medicine, 4, 16-24 [in Russian]. 10. Shulhai, A.H., Tatarchuk, L.V., \& Hnatiuk, M.S. (2017). Osoblyvosti remodeliuvania sudyn hemomikrotsyrkulatornoho rusla klubovoi kyshky pry rezektsii riznykh obiemiv pechinky [Remodeling peculiarities of ileum hemomicrocirculatory bed vessels at resection of different liver size]. Visnyk naukovyi doslidzen - Scientific Journal of Investigation, 4, 145-149 [in Ukrainian].

11. Nanashima, A., Sumida, Y., Abo, T. (2008). A modified grading system for post-hepatectomy metastatic liver cancer originating form colorectal carcinoma. J. Surg. Oncol., 98, 363-370. 
A. H. SHULGAI, L. V. TATARCHUK, M. S. HNATJUK

I. Horbachevsky Ternopil State Medical University

\title{
MORPHOMETRICAL ANALYSIS OF FEATURES REMODELING STRUCTURES OF ILEUM AT RESECTIONS OF DIFFERENT VOLUME OF LIVER PARENCHIMA
}

The aim of the work: morphological methods to study the features of remodeling of the structures of the ileum at resection of different volumes of liver parenchyma.

Materials and Methods. The complex of morphological methods examined the ileum of 45 mature hite white male rats, which were divided into 3 groups. The first group consisted of 15 intact animals, second - 15 rats, in which $31.5 \%$ of the liver parenchyma was removed, third -15 animals after resection of $58.1 \%$ of liver parenchyma. Euthanasia of rats was carried out by bloodletting in conditions of thiopental anesthesia 1 month after the beginning of the experiment. From the ileum histological preparations were made. The morphometry of thickness of the mucous, muscle, serous membranes, submucosal layers, length, width of villi, depth, width of crypts, height of cover epithelial cells, diameter of their nuclei, determined nuclear-cytoplasmic relations in epitheliocytes, relative volume of damaged epithelial cells, submucosal-mucous and submucosal-muscular indices stromal-myocytes ratio in the muscle of the organ were measured. Quantitative indicators were processed statistically.

Results and Discussion. It was established that after resection of $31.5 \%$ of liver parenchyma morphometric indices insignificantly changed. The morphometric parameters of the ileum structures in the month after resection of $58.1 \%$ of liver parenchyma were the most altered. At the same time, the thickness of the mucous membrane of the investigated organ with a high degree of reliability $(\mathrm{p}<0.001)$ decreased by $15.0 \%$, muscle - by $6.1 \%$, and the thickness of the submucosal layer increased by $7.4 \%$, the serous membrane - by $6.6 \%$. Submucosymucosal index increased by $27.2 \%$, and submucosal-muscle - by $14.4 \%$, compared with control morphometric indices. The length of the villi and the depth of the crypt of the ileum, the height of the epithelial cells were statistically significantly $(\mathrm{p}<0.001)$ decreased by $15.7 \%$, $15.4 \%$ and $14.7 \%$ respectively, while the width of the villi and crypt increased by $13.3 \%$ and $14.2 \%$ Nuclear-cytoplasmic ratios in the epitheliocytes of the ileum mucosa have been altered by $38.5 \%$, indicating a marked violation of structural cellular homeostasis. Relative volume of damaged epitheliocytes increased 28 times, and stromal-myocytic ratios in the muscular membrane increased by $22.6 \%$, indicating a pronounced increase in stroma in the muscle of the organ. The results of the study suggest that the removal of large volumes of liver parenchyma leads to pronounced morphological rearrangement (remodeling) of the structures of the ileum, characterized by uneven disproportionate changes in the spatial characteristics of the organ structure, violation of relations between them, vascular disorders, edema, dystrophic, necrobiotic changes in epitheliocytes, endothelial cells, stromal elements, infiltrative and sclerotic processes.

Key words: resection of the liver; ileum; remodeling.

\section{МОРФОМЕТРИЧЕСКИЙ АНАЛИЗ ОСОБЕННОСТЕЙ РЕМОДЕЛИРОВАНИЯ СТРУКТУР ПОДВЗДОШНОЙ КИШКИ ПРИ РЕЗЕКЦИЯХ РАЗНЫХ ОБЪЕМОВ ПАРЕНХИМЫ ПЕЧЕНИ}

\begin{abstract}
Цель работы: морфологическими методами изучить особенности ремоделирования структур подвздошной кишки при резекции разных объемов паренхимы печени.

Материалы и методы. Комплексом морфологических методов исследована подвздошная кишка 45 половозрелых белых крыссамцов, которые были разделены на 3-и группы. 1-я группа включала 15 интактных животных, 2-я - 15 крыс, у которых было удалено 31,5 \% паренхимы печени, 3-я - 15 животных после резекции 58, 1 \% паренхимы печени. Эвтаназия крыс осуществлялась кровопусканием в условиях тиопенталового наркоза через один месяц от начала эксперимента. Из подвздошной кишки изготовляли гистологические микропрепараты. Измеряли толщины слизистой, мышечной, серозной оболочек, подслизистого слоя, длину, ширину ворсинок, глубину, ширину крипт, высоту покровных эпителиоцитов, диаметр их ядер, определяли ядерно-цитоплазматические отношения у эпителиоцитах, относительный объем поврежденных эпителиоцитов, подслизисто-слизистый и подслизисто-мышечный индексы, стромально-миоцитарные отношения у мышечной оболочке органа. Количественные показатели обрабатывали статистически.

Результаты исследований и их обсуждение. Выявлено, что при резекции 31,5 \% паренхимы печени исследуемые морфометрические показатели изменялись незначительно. Наиболее измененными оказались морфометрические параметрь структур подвздошной кишки через месяц после резекции 58,1 \% паренхимы печени. При этом толщина слизистой оболочки исследуемого органа с высокой степенью достоверности (p < 0,001) уменьшилась на $15,0 \%$, мышечной - на $6,1 \%$, а толщина подслизистого слоя возросла на 7,4 \%, серозной оболочки - на 6,6 \%. Подслизисто-слизистый индекс увеличился на 27,2 \%, а подслизисто-мышечный - на 14,4 \%, в сравнении с контрольными морфометрическими показателями. Длина ворсинок и глубина крипт подвздошной кишки, высота эпителиоцитов статистически достоверно $(\mathrm{p}<0,001)$ уменьшились соответственно на 15,7 \%, 15,4 \% та 14,7 \%, а ширина ворсинок и крипт увеличилась на 13,3 \% и 14,2 \%. Ядерно-цитоплазматические отношения у эпителиоцитах слизистой оболочки подвздошной кишки были измененными на $38,5 \%$, что свидетельствовало о выраженном нарушении структурного клеточного гомеостаза. Относительный объем поврежденных эпителиоцитов увеличился у 28 раз, а стромально-миоцитарные отношения у мышечной оболочке - на 22,6 \%, указывая о выраженном возростанни стромы у мышечной оболочке органа. Результаты проведенного исследования подтверждают, что удаление больших объемов паренхимы печени приводит к выраженной морфологической перестройке (ремоделированню) структур подвздошной кишки, что характеризуется неравномерными диспропорциональными изменениями пространственных характеристик структур органа, нарушением отношений между ними, сосудистыми расстройствами, отеком, дистрофическими, некробиотическими изменениями эпителиоцитов, эндотелиоцитов, стромальных элементов, инфильтративными и склеротическими процессами.
\end{abstract}

Ключевые слова: резекция печени; подвздошная кишка; ремоделирование. 